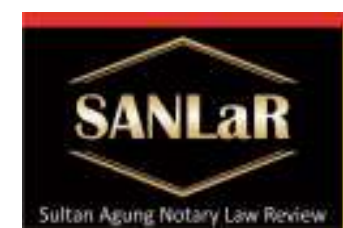

Volume 3 No. 2, June 2021
Sultan Aqung

Notary Law Review

Notaries Responsibilities in Receiving ...( Matthew Marcellinno Gunawan)

\title{
Notaries Responsibilities in Receiving Payment of Tax on Acquisition of Land \& Building Rights
}

\author{
Matthew Marcellinno Gunawan*) \\ *) Faculty of Law, Universitas Islam Sultan Agung (UNISSULA) Semarang, E-mail: \\ m.marcellinno@gmail.com
}

\begin{abstract}
Notary is one of the public officials (openbaar ambtenar) who is authorized to make all kinds of agreements in the form of authentic deeds, set the date, keep the deeds and issue grosses, copies and quotations, all of this as long as the act of the deed is not also required to other officials or specifically the obligation. However, it often happens that notaries do things outside their authority, one of which is as the party receiving the deposit of payment of fees for the acquisition of land and building rights. The formulation of this research isknow the responsibilities of the notary in terms of receiving the deposit of payment of taxes on the acquisition of land and building rights, then associated with the appropriate theory in order to draw hypotheses and be supported by research data in the field, as well as civil settlement in the event of a dispute. The method used in this research is the approach method in this writing is normative juridical, the specification of this research is descriptive analytical research. The data source uses secondary data. Data collection techniques using literature study or document study. The data analysis technique used a qualitative descriptive approach. The results of the research on the first and second conclusions. In terms of depositing fees for the acquisition of land and building rights, basically the notary's clients appear to be paying them, but in practice it is often found that notaries are trusted by many appearers/clients to pay the fees for the acquisition of land and building rights from their clients. Related to this, the laws and regulations do not regulate the authority of a Notary as a land deed official to pay land sale and purchase tax from his client or appearer, but if the appearers/clients authorize the notary concerned to represent to pay the land sale and purchase tax in the form of fees for the acquisition of land and building rights to the state treasury, the notary concerned basically does not have the authority to carry out the payment.
\end{abstract}

Keyword: Notary; Land \& Building Rights Acquisition Fees; Payment.

\section{Introduction}

Practically everything that exists in society has attachments and interrelationships with one another. Notaries themselves can also be subject to sanctions if they are proven to have violated the applicable provisions both in the professional code of ethics and the laws that regulate. If the notary's error can be proven, then a notary can be subject to sanctions that have been determined by law. The Notary Professional Organization, namely the Indonesian Notary Association (INI) has established a Professional Code of Ethics, namely the INI Code of Ethics, and for notaries only to the order of moral and 
administrative sanctions. ${ }^{1}$ Notaries in carrying out their duties must be carried out with full responsibility by respecting the dignity of their positions, as well as with the skills to serve the interests of the people who request their services always based on the provisions of the law, ethics, public order and good Indonesian language. ${ }^{2}$ Notaries as public officials whose duties are to serve the community are expected to contribute to the development of national laws that have high morals. Moral values are forces that direct and underlie an action, therefore Notaries are required to have strong morals. As a public official who is needed by the community, a notary must be able to provide reliable and trustworthy information. ${ }^{3}$

The notary's liability arising from an act that is not in accordance with applicable law is determined by the nature and legal consequences that arise. In general, the responsibilities that are usually imposed on notaries are criminal, civil, and administrative sanctions, as well as moral sanctions. This is a consequence of a violation or negligence committed by a notary in the process of making an authentic deed. Determining the existence of a civil or criminal liability for actions committed by a notary must meet certain conditions, among others, there must be a notary act that can be punished with elements that are expressly formulated in the law. The actions taken by the Notary must be contrary to the applicable laws and regulations/violate the provisions of the applicable law (acts against the law), and there must be an element of error in the form of intentional (dolus) or negligence (culpa). Therefore, the criminal responsibility of the Notary in carrying out his position must be seen whether or not there is an element of a criminal act or criminal act. A Notary as befits a human being who does not escape from mistakes, therefore in carrying out his duties and positions it is not uncommon for a Notary to commit acts that can be categorized as acts against criminal law. The unlawful act is carried out either intentionally or by negligence, making the Notary must undergo legal processes in the realm of criminal law. ${ }^{4}$

Law in reality is not a separate material subject because it is implemented in everyday reality. It will not only be carried out by people who have special professions in the legal field such as judges, prosecutors, police and so on, but will also involve people from other professional groups such as teachers, social workers, managers of government officials. unions, labor, and so on. Satjipto Rahardjo emphasized that the law is a human work in the form of norms containing behavioral instructions. Law is a reflection of human will about how society should be fostered and where it should be directed. Therefore, in the first place the law contains a record of the ideas chosen by the society in which the law was created. These ideas are ideas about justice. ${ }^{5}$ People

\footnotetext{
${ }^{1}$ Ikatan Notaris Indonesia, 2008, Jati Diri Notaris Indonesia, Dulu, Sekarang dan Di Masa Datang, PT. Gramedia, Jakarta, p. 93-94

${ }^{2}$ C.S.T Kansil, 2006, Pokok-Pokok Etika Profesi Hukum, PT. Pradnya Paramita, Jakarta, p.87.

${ }^{3}$ Tan Thong Kie, 2013, Studi Notariat dan Serba Serbi Praktek Notaris, PT. Ichtiar Baru Van Hoeve, Jakarta, p. 162

${ }^{4}$ Mulyoto, 2011, Kriminalisasi Notaris Dalam Pembuatan Akta Perseroan Terbatas, Cakrawala Media, Yogyakarta, p.39.

${ }^{5}$ Anthon F. Susanto, 2004, Wajah Peradilan Kita, PT. Refika Aditama, Bandung, p.46.
} 
not only want to see justice created in society and their interests served by law, but they also want that in society there are regulations that guarantee certainty in their relationships with one another. Therefore, the construction process contains demands for three things which Gustav Radbruch calls the basic values of law, namely justice, usefulness and legal certainty. ${ }^{6}$

Notaries are like human beings who are not free from mistakes. In this case, quite a number of notaries have stumbled into legal problems, both issues that are not realized or realized by the person concerned. One of the cases that has occurred is the misuse of trust by using money to pay taxes on the acquisition of land and building rights which were deposited by the client to the notary concerned ${ }^{7}$.

\section{Research methods}

The data that has been obtained will be analyzed using qualitative methods, namely by using legislation, opinions of legal experts, books or literature related to research, providing a systematic description of the facts, characteristics, and symptoms generated in relation to the law that is still in force with the data obtained, then conclusions are drawn by being described in descriptive writing.

The data is then analyzed using theory and positive law that has been poured then deductively drawn conclusions to answer the problem.

\section{Result and Discussion}

Responsibilities of Notaries in Receiving Deposits of Payment of Taxes on Acquisition of Rights on Land and Buildings

The position of a notary as a functionary in society as an official who can be relied on by the community. A notary is usually considered an official from whom one can obtain reliable advice. Everything that is written and stipulated is correct, a notary is a strong document maker in a legal process. ${ }^{8}$ Notaries are officials who are authorized to make authentic deeds, this authority is given based on the Civil Code as contained in Article 1868. As for strengthening the provisions contained in Article 1868 of the Civil Code, the Law on Notary Positions is promulgated as one of the legal products that regulate notaries. One of the things regulated in the Law on Notary Positions is regarding the authority of a Notary.

Article 15 paragraph (1) of the Law on Notary Positions states that a Notary is authorized to make an authentic deed regarding all acts, agreements, and provisions required by laws and/or desired by the interested parties to be stated in an authentic deed, guaranteeing certainty. the date of making the deed, keeping the deed, giving the grosse, copies and quotations of the deed, all of that as long as the making of the deed is not assigned or excluded to other officials or other people stipulated by law.

\footnotetext{
${ }^{6}$ Satjipto Rahardjo, 1996, Ilmu Hukum, Citra Aditya Bhakti, Bandung, p.19.

7 PMD Pratama - http://jurnal.unissula.ac.id > akta 2018 - 36 of 2016 regarding Income Tax on Income From the Transfer of Rights to Land and / or Buildings, And Agreements sale and purchase Land.

${ }^{8}$ Than Thong Kie, Op.cit, p.444
} 
The authority contained in Article 15 of the Law on Notary Positions is not only limited to making authentic deeds, but is also given other powers as stated in Article 15 paragraph (2) of Act No. 2 of 2014 concerning amendments to Act No. 30 of 2004 concerning the Notary Position, namely:

1. ratify the signature and determine the certainty of the date of the letter under the hand by registering it in a special book;

2. record the letters under the hand by registering in a special book;

3. make copies of the original underhand letters in the form of copies containing descriptions as written and described in the letter concerned;

4. validate the compatibility of the photocopy with the original letter;

5. provide legal counseling in connection with the making of the deed;

6. make a deed related to land; or

7. make a deed of auction minutes.

The authority given to a Notary is an attribution authority, this is because the authority is granted by Act No. 2 of 2014 concerning amendments to Act No. 30 of 2004 concerning the Position of a Notary. The authority that exists in a Notary does not come from other government institutions, but the authority that is based on and granted by law. Therefore, the authority possessed by a Notary is the Attribution authority.

One of the powers granted by the law is the authority to make a deed related to land. This authority is stated in Article 15 paragraph (2) letter f of Act No. 2 of 2014 concerning amendments to Act No. 30 of 2004 concerning the Position of Notary. Juridically, this authority has been given by law, but in practice the notary has not been able to make a deed related to land. At this time the making of deeds related to land made by a notary is still limited. The limitation of the authority possessed by a notary in making a deed on land is because there are other officials who are given the authority to make a deed on land, namelyLand Deed Making Officer (PPAT). Land Deed Making Officer (PPAT) given the authority by PP No. 37 of 1998. The authority granted to Land Deed Making Officer (PPAT) This can also be said attribution, this is because the granting of authority is directly given by legislation.

The authority of a notary is already limited in Article 15 paragraph (1) of Act No. 2 of 2014 concerning amendments to Act No. 30 of 2004 concerning the position of a notary. This limitation applies if there are other officials who are given the authority to make authentic deeds regulated in other laws. Therefore, if there is an official who can make an authentic deed and is mentioned in the law, the notary must give the authority to make the deed to the official specified in the law. Therefore, as long as the authority in the formation of the authentic deed is not regulated by other laws, the notary is authorized to make the deed.

In terms of depositing feesLand and Building Rights Acquisition Fee (BPHTB) basically deposited by the appearers of the notary clients, but in practice it is often found that 
the notaries are trusted by the appearers/clients to pay Land and Building Rights Acquisition Fee (BPHTB) from his client. In this regard, the laws and regulations do not regulate the authority of a Notary as aLand Deed Making Officer (PPAT) to pay the sale and purchase tax of land from the client or the appearer, but if the appearer/client authorizes the notary concerned to represent to pay the land sale and purchase tax in the form of Land and Building Rights Acquisition Fee (BPHTB)to the state treasury, the notary concerned must be responsible on the basis of the trust given by the party in charge. In this case the notary acts outside his authority as a notary, but carries out an agreement both verbally and in writing, becauseArticle 1338 paragraph (1) of the Civil Code, which explains "All agreements are made legally valid as law for those who make them" means that if an agreement has been reached, both oral and written, it will automatically bind both parties the parties agree to it. If a notary does not do it properly, then a litigation or non-litigation settlement can be carried out because he has broken his promise or is in default. So in terms of the notary's responsibility in receiving payment depositsLand and Building Rights Acquisition Fee (BPHTB) from his client, a notary acts not based on position, but based on an agreement as a party ${ }^{9}$.

\section{Closing}

\subsection{Conclusion}

Fee paymentLand and Building Rights Acquisition Fee (BPHTB) basically deposited by the appearers or clients of the notary, but in practice it is often found that the notary is trusted by the appearers/clients to pay Land and Building Rights Acquisition Fee (BPHTB) from his client. In this regard, the laws and regulations do not regulate the authority of a Notary as aLand Deed Making Officer (PPAT) to pay the sale and purchase tax of land from the client or the appearer, but if the appearer/client authorizes the notary concerned to represent to pay the land sale and purchase tax in the form of Land and Building Rights Acquisition Fee (BPHTB)to the state treasury which of course uses a power of attorney, the notary concerned must be responsible on the basis of the power of attorney granted by the party in charge. In this case the notary acts outside his authority as a notary, but carries out an agreement both verbally and in writing as a party, becauseArticle 1338 paragraph (1) of the Civil Code, which explains "All agreements are made legally valid as law for those who make them" means that if an agreement has been reached, both oral and written, it will automatically bind both parties the parties agree to it. If a notary does not do it properly, then a litigation or non-litigation settlement can be carried out because he has broken his promise or is in default.

\subsection{Suggestion}

It is recommended that in carrying out their duties and positions as a notary, notaries adhere to what has been promulgated regarding the authority of a notary in order to maintain legal certainty, both the notary himself and the party in charge of the custody of the payment of fees for the acquisition of land and building rights, even though in

\footnotetext{
9 Roles And Responsibilities Of Land Agreement Official Tax/http://jurnal.unissula.ac.id / article / download, by AD Zahirani 2018 - Agreement Official / Notaries only can sign the agreement of Transfer of Rights to Land
} 
Article 1338 paragraph ( 1) Written Civil Code all agreements made legally in accordance with the law apply as law to those who make it as a legal basis.

5. References

Journals:

[1] PMD Pratama · http://jurnal.unissula.ac.id > akta 2018 - 36 of 2016 regarding Income Tax on Income From the Transfer of Rights to Land and / or Buildings, And Agreements sale and purchase Land.

Roles And Responsibilities of Land Agreement Official Tax/http://jurnal.unissula.ac.id > article > download, by AD Zahirani · 2018 Agreement Official / Notaries only can sign the agreement of Transfer of Rights to Land

Books:

[1] Anthon F. Susanto, 2004, Wajah Peradilan Kita, PT. Refika Aditama, Bandung

[2] C.S.T Kansil, 2006, Pokok-Pokok Etika Profesi Hukum, PT. Pradnya Paramita, Jakarta

[3] Ikatan Notaris Indonesia, 2008, Jati Diri Notaris Indonesia, Dulu, Sekarang dan Di Masa Datang, PT. Gramedia, Jakarta, p. 93-94

[4] Mulyoto, 2011, Kriminalisasi Notaris Dalam Pembuatan Akta Perseroan Terbatas, Cakrawala Media, Yogyakarta

[5] Satjipto Rahardjo, 1996, Ilmu Hukum, Citra Aditya Bhakti, Bandung

[6] Tan Thong Kie, 2013, Studi Notariat dan Serba Serbi Praktek Notaris, PT. Ichtiar Baru Van Hoeve, Jakarta 